\title{
A Simple Inexpensive Method for the Measurement of Indoleacetamide Hydrolase Activity
}

\author{
Kim Z. Gamburg \\ Siberian Institute of Plant Physiology and Biochemistry, Siberian Branch of the Russian Academy of Sciences, \\ Irkutsk, Russia \\ Correspondence to: Kim Z. Gamburg, gamburg@sifibr.irk.ru \\ Keywords: Auxin, Indolyl-3-Acetic Acid Synthesis, Indolyl-3-Acetamide, Indolyl-3-Acetamide Hydrolase, \\ Scorzonera hispanica L., Daucus sativus (Hoffm.) Roehl., Cucurbita pepo L \\ Received: March 20, $2017 \quad$ Accepted: April 27, $2017 \quad$ Published: April 30, 2017 \\ Copyright (C) 2017 by authors and Scientific Research Publishing Inc. \\ This work is licensed under the Creative Commons Attribution International License (CC BY 4.0). \\ http://creativecommons.org/licenses/by/4.0/

\section{c) (i) Open Access}

\section{ABSTRACT}

Indole-3-acetic acid (IAA) a phytohormon of auxin type is synthesized by different ways in plants and some bacteria (Agrobacteria, Pseudomonas and some others). The enzyme indolylacetamide hydrolase transforms indolylacetamide to IAA mainly in bacteria. However, recently published data showed that some plants can also hydrolyze indolylacetamide into IAA. In order to elucidate the role of indolylacetamide as an auxin precursor in plants and bacteria, productive method of determination of the activity of indoleacetamide hydrolase is necessary. The simple, inexpensive and productive method for the measurement of indoleacetamide hydrolase activity was elaborated based on significant difference between IAAM and IAA in color developed with Salkovski' reagent. The light absorbance increased during conversion of IAAM to IAA by protein extracts from some plant cells and this increase may be used for quantitative estimation of indoleacetamide hydrolase activity. The method is suitable for fast discovery of indoleacetamide hydrolase activity before planning more complicated analyses and for the analysis of many probes at a short time in physiological and biochemical experiments. A detailed protocol for determination of indoleaceta- mide hydrolase activity by the elaborated method is described.

\section{INTRODUCTION}

Indole-3-acetic acid (IAA) is a multifunctional phytohormone playing important role in the regulation of plant growth and development. Many studies were devoted to the elucidation the ways of its metabolism, i.e. biosynthesis and inactivation [1]. To date, two routes of IAA biosynthesis are postulated: 1) prokaryotic one, which was discovered at first in Agrobacteria, Pseudomonas and some other bacteria, 2) eukaryotic one which is peculiar to plants. The synthesis of IAA according to the first route proceeds by conversion of L-Try to indoleacetamide (IAAM) catalyzed with tryptophan-2-monooxigenase and its hy- 
drolysis to IAA with IAAM hydrolase (IAAMH). These bacteria have two genes: one for tryptophan-2-monooxigenas $(a u x 1)$ and other one for IAAMH $(a u x 2)$. In plants (second route of IAA synthesis), L-Try is converted to indole-3-pyruvic acid (IPA) with the participation of tryptophan aminotransferase and with following IPA decarboxylation to indole-3-acetaldehyde and oxidation to IAA. However, now there are many evidences that some plants can use the prokaryotic route for IAA synthesis also [2-6]. Mano and Nemoto [6] cited several publications on the presence of IAAM in non-transformed plants with the contents of $1-10 \mathrm{ng}$ per $1 \mathrm{~g} \mathrm{FW}$. This level of IAAM contents is comparable to the contents of IAA. However, sequences similar to aux 1 were not found in plant genomes. Some authors did not mention IAAM among isolated indole compounds $[7,8]$. It is known that amides are not very stable compounds, they cannot be sterilized in autoclave. Sequences similar to aux 2 gene (coding IAAMH) were found in many plant genomes $[7,9]$. However, there are many other amidohydrolases which can hydrolyse IAA amino acid conjugates [10] and other amides. Genes coding these amidohydrolases may have aux2-like but not identical sequences. So, the presence of aux2-like sequences in plant genomes is not a decisive proof of the presence of IAAMH in them. Besides of this, it is a long way from the presence of gene in genomic DNA to its real participation in plant metabolism because this presence is not always resulted in the appearance of protein coded by the gene. There may be two final proofs of IAAMH activity in plants: the ability of IAAM to be a substitute of IAA and other auxins in plant growth regulation and the ability of plant extracts to transform IAAM to IAA.

IAAMH activity has been measured by several authors [2-12]. Methods used by them need to apply extraction of IAA and IAAM from reaction medium, separation of them from each other and determination of their quantities with different chromatographic equipment. These methods are time and labor consuming and needs highly expensive equipment (LC-MS or GC-MS). They do not give the possibility to measure IAAMH activity in many probes at a short time. The need for such measurements is especially acute in studies on the participation of IAAMH in regulation of biochemical and physiological processes in plants.

The need for more simple productive and less expensive method for the estimation of IAAMH activity has been appeared when we performed experiments on the correlations between the growth of auxin-independent (transformed by wild strains of Agrobacterium tumefaciens) cell and tissue cultures and IAAMH activity. After some time, we elaborated such method which we want to present in this communication. The method is based on the high difference of coloration with Salkowski's reagent between IAA and IAAM.

\section{MATERIALS AND METHODS}

Transformed cell cultures of Sorsonera hispanica L. and Daucus sativus (Hoffm.) Roehl. were applied in this work. Their origin and cultivation were described in our previous publication [13]. Transformed nature of these cultures has been confirmed by the presence of octopine in them and by the ability to grow in vitro without auxin. Cells were separated from the medium on glass filter and portions of $1.5 \mathrm{~g} \mathrm{FW}$ were frozen and stored in liquid $\mathrm{N}_{2}$.

Obtaining protein extracts was performed as described by Ishikawa et al. [11] with some modifications. Cells were homogenized in chilled mortar and pestle at $4^{\circ} \mathrm{C}$ with the addition of $1.5 \mathrm{ml}$ of A buffer $(100 \mathrm{mM}$ tris- $\mathrm{HCl}, 10 \mathrm{mM} \mathrm{MgCl}_{2}, 50 \mathrm{mM} \mathrm{KCl}, 5 \mathrm{mM}$ EDTA, $10 \mathrm{mM} \beta$-mercaptoethnol, $10 \%$ saccharose, $\mathrm{pH}$ 8,0). The homogenate was centrifuged $20 \mathrm{~min}$ at $10000 \times \mathrm{g}$ and $\beta$-mercaptoethnol and saccharose were removed from the supernatant on Sefadex G25 column. The removal of $\beta$-mercaptoethnol is necessary because it diminishes significantly the coloration with Salkowsky's reagent [14]. Reaction mixture containing protein extract 0.6 $\mathrm{ml}, 0.1 \mathrm{ml}$ of $4.6 \mathrm{mM}$ IAAM (or IAA) and buffer A without $\beta$-mercaptoethnol and saccharose (total volume $1 \mathrm{ml}$ ) was incubated in darkness at $37^{\circ} \mathrm{C}$. After incubation, $0.2 \mathrm{ml}$ of the reaction mixture was mixed with 0.8 $\mathrm{ml}$ of water and $2 \mathrm{ml}$ of Salkowsky's reagent as described by Sarwar et al. [14] (2 $\mathrm{ml} 0.5 \mathrm{M} \mathrm{FeCl}_{3}+98 \mathrm{ml} 37 \%$ $\mathrm{HClO}_{4}$ ) and incubated in darkness for $45 \mathrm{~min}$. Measurement of color intensity was performed at $530 \mathrm{~nm}$ (see Figure 1). Two probes have been made at time zero, one with IAAM and other with IAA. 


\section{RESULTS}

As shown in Figure 1, colors developed after mixing IAA and IAAM solutions with Salkowsky's reagent had an absorption maximum at $530 \mathrm{~nm}$, but it was 3.4 times higher for IAA than for IAAM. It means that amount of absorption will be increased during conversion of IAAM to IAA in the course of IAAMH action because molar coefficient of absorption at $530 \mathrm{~nm}\left(\alpha_{530}\right)$ was $1.63 \times 10^{-3} \times \mathrm{mM}^{-1}$ for IAAM and 5.52 $\times 10^{-3} \times \mathrm{mM}^{-1}$ for IAA.

We performed model experiment in which some amounts of IAA was added to constant amount of IAAM and colored this mixture with Salkowsky's reagent. It can be seen in Figure 2 that color intensity was increased according to the increase of IAA per cent in mixture. So, measurement of reaction mixture for determination of IAAMH colored with Salkowsky's reagent may be used for the estimation of its activity.

The formula is proposed for quantitative estimation of IAAMH activity:

$$
A=\frac{E_{t}-E_{0}}{E_{i}-E_{0}} \times \frac{460 \mathrm{~V}}{v t m}
$$

where $A$ is IAAMH activity in nmoles of IAA appeared (or IAAM disappeared) per $1 \mathrm{~g}$ FW per $1 \mathrm{~h}, E_{0}$ is absorption of reaction mixture contained 460 nmoles IAAM at time zero and colored with Salkowsky's reagent, $E_{t}$ is absorption of reaction mixture after some time $t$ (hours), $E_{i}$ is absorption of reaction mixture contained 460 nmoles of IAA at time zero, $V$ is total volume of protein extract, $V$ is the volume of protein extract added into reaction mixture $(0.6 \mathrm{ml}), m$ is FW of plant tissue used for the obtaining protein extract. If $p$ (concentration of protein per $1 \mathrm{ml}$ of pro tein extract) will be included into the formula instead of $m$, the IAAMH activity will be expressed as nmoles per $\mathrm{mg}$ protein. The first part of this formula estimates which proportion of IAAM was converted to IAA and the second part transforms this proportion to nmoles of IAA per $1 \mathrm{~g} F W$ per $1 \mathrm{~h}$.

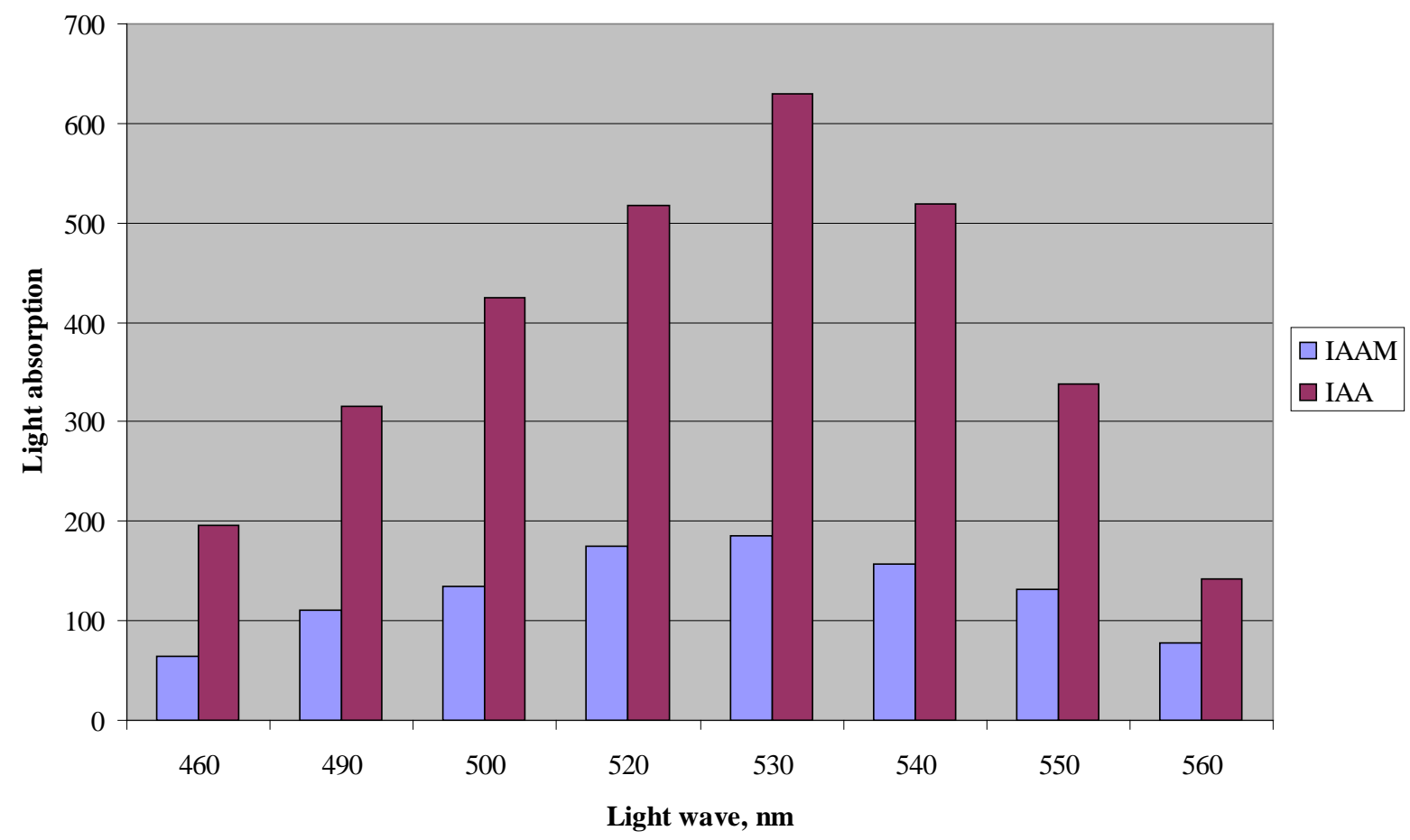

Figure 1. Specters of IAAM and IAA $(114 \mathrm{mM})$ colored with Salkowsky's reagent. Amounts of absorption $\times 10^{3}$. 


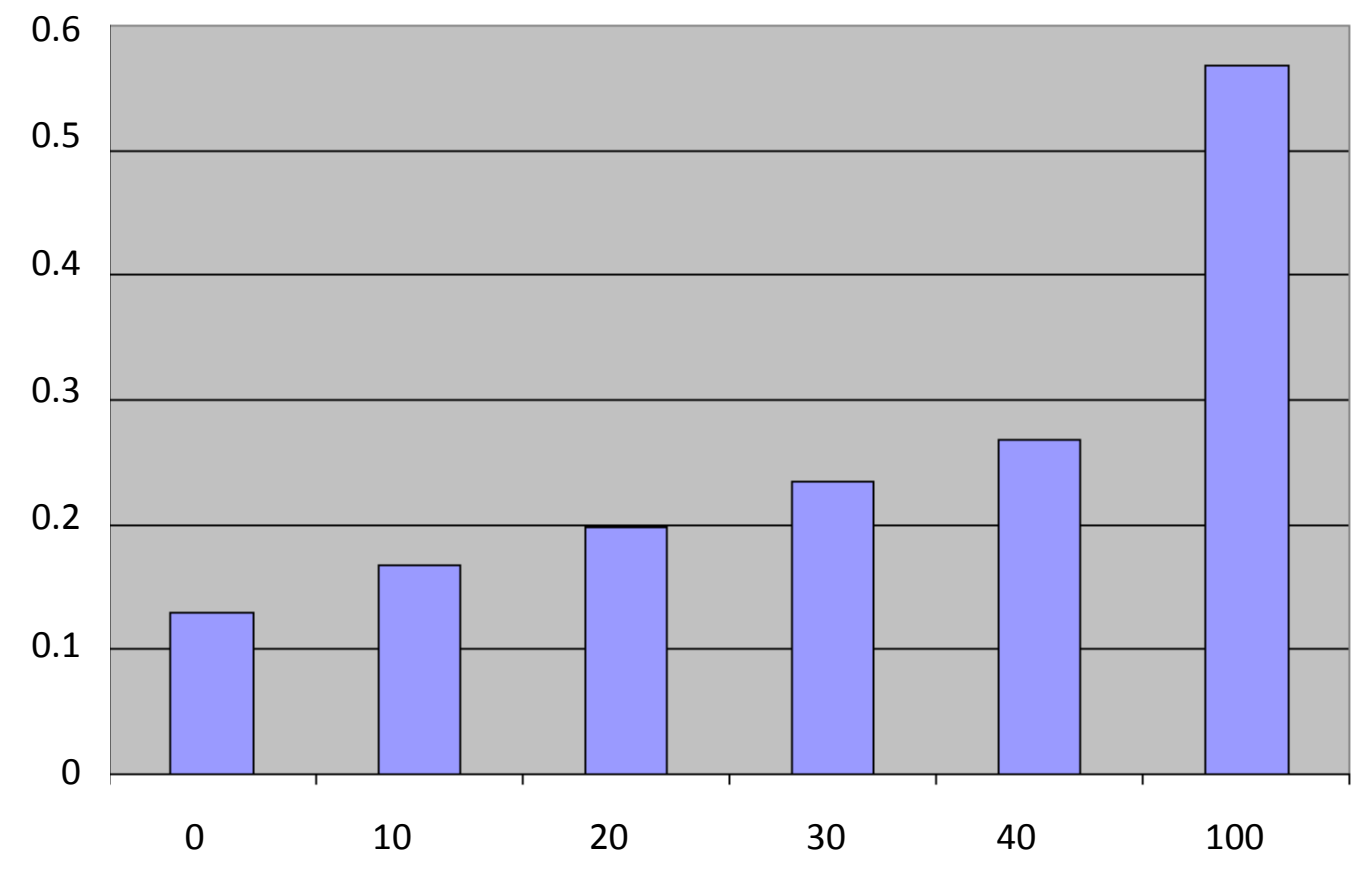

Figure 2. Effect of IAA addition to IAAM on the intensity of color reaction with Salkowsky's reagent. Abscissa-\% of IAA in mixture with IAAM, ordinate-light absorption at $530 \mathrm{~nm}$.

In order to know, if the rate of the conversion is proportional to the amount of protein extract added to reaction mixture, experiments were performed in which protein extract was diluted with buffer B two or four times before its addition. As shown in Table 1, the rate of conversion calculated on undiluted protein extract did not depended on the dilution, but the time length of constant rate of conversion was increased due to the dilution. After this time the rate was slowed down. These data illustrate that proposed method can be used for quantitative measurement of IAAMH activity.

As an example of the applicability of the method, the data on the IAAMH activity in $S$. hispanica, $D$. sativus cells (transformed with wild strains of Agrobacterium tumefaciens) cultured in vitro and seedlings of Cucurita pepo are presented in Table 2. It may be seen that scorzonera cell culture possessed higher activity than carrot one. We confirmed data published by Rajagopal et al. [4] on the presence of IAAMH activity in squash seedlings with the use of the method described in this work. However, this activity was 50 - 160 times less than activity in transformed cells of $D$. sativus and S. hispanica. These data illustrate the suitability to use the method described for comparison of IAAMH activity in different plant objects.

As shown in Table 3, only NAAM inhibited IAAMH activity, whereas other amides had no influence. Thus, it is a concurrent inhibitor of IAAMH. On this ground, it may be supposed that the observed amidase activity is specific for IAAM because IAAM and NAAM possess similar chemical structures and IAA and NAA both are auxins (one of them is natural and second one is synthetic). NAAM was used for the mass selection of spontaneous tomato haploids because seeds of diploid F-1 hybrids between wild and transgenic (possessing IAAMH gene) plants did not give normal seedlings in its presence due to NAA release from NAAM with IAAMH [15]. Other amides are evidently hydrolyzed by some other amido hydrolases.

\section{CONCLUSION}

The simple, inexpensive and productive method for the measurement of IAAMH activity was elaborated based on significant difference between IAAM and IAA in color developed with Salkovski' reagent. 
The light absorbance increased during conversion of IAAM to IAA by protein extracts from some plant cells and this increase may be used for quantitative estimation of IAAMH activity. The method has no need for extraction and chromatographic separation of IAA and IAM. It will be suitable for fast discovery of IAAMH activity before planning more complicated analyses and for the analysis of many probes at a short time in physiological and biochemical experiments. Our data (Table 2) shows that IAAMH activity, if it presents in not tumorous plant cells, may be significantly less than in tumorous ones.

\section{PROTOCOL}

Prepare:

- buffer A: $100 \mathrm{mM}$ tris- $\mathrm{HCl}, 10 \mathrm{mM} \mathrm{MgCl}$, $50 \mathrm{mM} \mathrm{KCl,} 5 \mathrm{mM}$ EDTA, $10 \mathrm{mM} \beta$-mercaptoethnol, $10 \%$ saccharose, $\mathrm{pH} 8,0$;

- buffer B: the same as buffer A, but without $\beta$-mercaptoethnol and saccharose;

Table 1. The rate of conversion of IAAM to IAA in dependence on the dilution of protein extract from scorzonera hispanica cells cultured in vitro. $\mathrm{D}$ : dilution (times), $\mathrm{R}$ : rate of conversion (nmoles IAA per $1 \mathrm{~h}$ calculated per not diluted extract), L: length of the period of constant rate of the conversion $(\mathrm{h})$.

\begin{tabular}{ccc}
\hline $\mathrm{D}$ & $\mathrm{R}$ & $\mathrm{L}$ \\
\hline 0 & 10.3 & 1 \\
2 & 10.9 & 2 \\
4 & 10.0 & $\geq 4$ \\
\hline
\end{tabular}

Table 2. IAAMH activity in some plant objects.

\begin{tabular}{cc}
\hline Plant objects & IAAMH activity, $\mathrm{nmoles}^{-1} \cdot \mathrm{g}^{-1} \mathrm{FW}$ \\
\hline Etiolated squash seedlings & $0.3-0.6^{*}$ \\
Transformed carrot cell culture & $15-21$ \\
Transformed scorzonera cell culture & $50-100$ \\
\hline
\end{tabular}

*data of experiments performed at different times

Table 3. The effects of several amides on the activity of IAAMH extracted from Scorzonera hispanica cells cultured in vitro.

\begin{tabular}{cc}
\hline Amides $^{\star}$ & IAAMH activity, \% \\
\hline- & 100 \\
Glutamine & 96 \\
Acetamid & 100 \\
Nicotinamid & 109 \\
Naphthylacetamid (NAAM) & 44 \\
\hline
\end{tabular}

*amides were added into the reaction medium at the same concentration and simultaneously with IAAM. 
- several columns of Sephadex G-25;

- solutions of IAAM and IAA $4.6 \mathrm{mM}$ in buffer B;

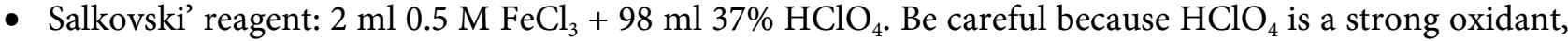
so as $\mathrm{H}_{2} \mathrm{SO}_{4}$ is;

- store them in refrigerator at $4^{\circ} \mathrm{C}$ before use.

- Instruments:

- spectrophotometer;

- incubator for $37^{\circ} \mathrm{C}$;

- glass vials for liquid volumes of $3 \mathrm{ml}$ or a little more;

- centrifuge for $10000 \times \mathrm{g}$ and $4^{\circ} \mathrm{C}$.

- The procedure:

- take probes of plant material and store them in liquid nitrogen or in refrigerator at $-80^{\circ} \mathrm{C}$;

- rub them in chilled mortar and pestle at $4^{\circ} \mathrm{C}$ with equal volume $(\mathrm{ml} / \mathrm{g})$ of buffer $\mathrm{A}$;

- centrifuge $20 \mathrm{~min}$ at $10000 \times \mathrm{g}$ and $4^{\circ} \mathrm{C}$;

- pass supernatant through Sephadex G-25 column with buffer B and make the desirable volume of eluate with buffer B; (use only fractions containing proteins);

- prepare reaction mixtures of $0.1 \mathrm{ml}$ of $4.6 \mathrm{mM}$ IAAM in buffer B with $0.6 \mathrm{ml}$ of the eluate, make total volume to $1 \mathrm{ml}$ with buffer B and mix immediately $0.2 \mathrm{ml}$ with $0.8 \mathrm{ml}$ water and $2 \mathrm{ml}$ of Salkowsky's reagent for estimation of $E_{\delta}$;

- prepare reaction mixture of $0.1 \mathrm{ml}$ of $4.6 \mathrm{mM}$ IAA in buffer B with $0.6 \mathrm{ml}$ of the eluate, make total volume to $1 \mathrm{ml}$ with buffer B and mix immediately $0.2 \mathrm{ml}$ with $0.8 \mathrm{ml}$ water and $2 \mathrm{ml}$ of Salkowsky's reagent for estimation of $E_{\vec{p}}$

- incubate probes containing IAAM and protein extract at $37^{\circ} \mathrm{C}$ for some time and mix $0.2 \mathrm{ml}$ of reaction mixtures with $0.8 \mathrm{ml}$ water and $2 \mathrm{ml}$ of Salkowsky's reagent for estimation of $E_{\dot{p}}$

- incubate IAAM and IAA mixtures with Salkowsky's reagent at room temperature in darkness for 45 $\min$;

- measure light absorbance at $530 \mathrm{~nm}$;

- calculate the activity of IAAMH with the formula:

$$
A=\frac{E_{t}-E_{0}}{E_{i}-E_{0}} \times \frac{460 \mathrm{~V}}{v t m}
$$

where $A$ is IAAMH activity in nmoles per $1 \mathrm{~g} \mathrm{FW,} E_{0}$ is absorption of reaction mixture contained 460 nmoles IAAM at time zero and colored with Salkowsky's reagent, $E_{t}$ is absorption of reaction mixture after some time $t$ (hours), $E_{i}$ is absorption of reaction mixture contained 460 nmoles of IAA at time zero, $V$ is total volume of protein extract, $V$ is the volume of protein extract added into reaction mixture $(0.6 \mathrm{ml}), \mathrm{m}$ is FW of plant tissue used for the obtaining protein extract. If protein content (mg per $1 \mathrm{ml}$ of the eluate) is known, the activity can be calculated on $\mathrm{mg}$ of protein.

\section{ACKNOWLEDGEMENTS}

I appreciate the participation of T. A. Markova, L. V. Gamanets and A. G. Enikeev during fulfillment of experiments.

\section{REFERENCES}

1. Zhao, Y. (2010) Auxin Biosynthesis and Its Role in Plant Development. Annual Review of Plant Biology, 61, 49-64. https://doi.org/10.1146/annurev-arplant-042809-112308

2. Kawaguchi, M., Kobayashi, M., Sakurai, A. and Syōno, K. (1991) Presence of an Enzyme That Converts Indole-3-Acetamide into IAA in Wild and Cultivated Rice. Plant and Cell Physiology, 32, 143-149.

https://doi.org/10.1093/oxfordjournals.pcp.a078058 
3. Kawaguchi, M., Fujioka, S., Sakurai, A., Yamaki, T.Y. and Syōno, K. (1993) Presence of a Pathway for the Biosynthesis of Auxin via Indole-3-Acetamide in Trifoliata Orange. Plant and Cell Physiology, 34, 121-128.

4. Rajagopal, R., Tsurusaki, N., Kannangara, G., Kuraishi, S. and Sakurai, N. (1994) Natural Occurrence of Indoleacetamide and Amidohydrolase Activity in Etiolated Aceptically Grown Squash Seedlings. Plant and Cell Physiology, 35, 329-339.

5. Lehmann, T., Hoffmann, M., Hentrich, M. and Pollmann, S. (2010) Indole-3-Ace- tamide-Dependent Auxin Biosynthesis: A Widely Distributed Way of Indole-3-Acetic Acid Production? European Journal of Cell Biology, 89, 895-905.

6. Mano, N.M. and Nemoto, R.A. (2012) The Pathway of Auxin Biosynthesis in Plants. Journal of Experimental Botany, 63, 2853-2872. https://doi.org/10.1093/jxb/ers091

7. Cooney, T.P. and Nonhebel, H.M. (1991) Biosynthesis of Indole-3-Acetic Acid in Tomato Shoots: Measurement, Mass-Spectral Identification and Incorporation of $2 \mathrm{H}$ from $2 \mathrm{H} 2 \mathrm{O}$ into Indole-3-Acetic Acid, D- and L-Tryptophan, Indole-3-Pyruvate and Tryptamine. Planta, 184, 368-376. https://doi.org/10.1007/BF00195339

8. Yu, P., Hegeman, A.D. and Cohen, J.D. (2014) A Facile Means for the Identification of Indolic Compounds from Plant Tissues. The Plant Journal, 79, 1065-1075. https://doi.org/10.1111/tpj.12607

9. Mano, Y., Nemoto, K., Suzuki, M., Seki, H., Fujii, I. and Muranaka, T. (2010) The AMI1 Gene Family: Indole-3-Acetamide Hydrolase Functions in Auxin Biosynthesis in Plants. Journal of Experimental Botany, 61, 25-32. https://doi.org/10.1093/jxb/erp292

10. Leong, S.S., Chiu, W.-C. and Chou, J.-C. (2009) Gene Cloning, Nucleotide Analysis, and from Over Expression in Escherichia coli of a Substrate-Specific Indole-3- Acetyl-L-Alanine Hydrolase Arthrobacter ilicis. Botanical Studies, 50, 11-20.

11. Ishikawa, K., Kamada, H. and Harada, H. (1988) Morphology and Hormone Levels of Tobacco and Carrot Tissues Transformed by Agrobacterium tumefaciens. II. IAA Biosynthetic Activity of Cultured Carrot Tissues Transformed with Wild and Mutant Ti-Plasmid. Plant and Cell Physiology, 29, 1171-1175.

12. Pollmann, S., Duchting, P. and Weiler, E.W. (2009) Tryptophan-Dependent Indole-3-Acetic Acid Biosynthesis by "IAA-Synthase" Proceeds via Indole-3-Aceta- mide. Phytochemistry, 70, 523-531.

13. Markova, T.A., Gamburg, K.Z., Gamanetz, L.V. and Enikeev, A.G. (1995) Aktivnost. indoleacetamide hydrolase in the Transformed Cells of scorzonera and Carrot. Fiziologiya Rasteniy, 42, 672-678. (In Russ)

14. Sarwar, M., Arshad, M., Martens, D.A. and Frankenberger, N.T. (1992) Tryptophan-Dependent Biosynthesis of Auxin in Soil. Plant and Soil, 147, 207-215. https://doi.org/10.1007/BF00029072

15. Hamza, S., Camillieri, C., Pollien, J.-M., Vaucheret, H., Boargin, J.-P. and Chupeau, Y. (1993) Selection for Spontaneous Tomato Haploids Using a Conditional Lethal Marker. Theoretical and Applied Genetics, 86, 657-664. https://doi.org/10.1007/BF00222653 
Submit or recommend next manuscript to SCIRP and we will provide best service for you:

Accepting pre-submission inquiries through Email, Facebook, LinkedIn, Twitter, etc. A wide selection of journals (inclusive of 9 subjects, more than 200 journals)

Providing 24-hour high-quality service

User-friendly online submission system

Fair and swift peer-review system

Efficient typesetting and proofreading procedure

Display of the result of downloads and visits, as well as the number of cited articles Maximum dissemination of your research work

Submit your manuscript at: http://papersubmission.scirp.org/

Or contact ns@scirp.org 